\title{
Markov Chain Analysis of Weekly Rainfall Data in Determining Drought-proneness
}

\author{
PABITRA BANIK $^{\mathrm{a}, *}$, ABHYUDY MANDAL ${ }^{\mathrm{a}}$ and M. SAYEDUR RAHMAN ${ }^{\mathrm{b}, \dagger}$ \\ ${ }^{\mathrm{a}}$ Agricultural Science Unit, Indian Statistical Institute, Calcutta 700 035, India; \\ ${ }^{\mathrm{b}}$ Associate Professor, Department of Statistics, Rajshahi University, Bangladesh
}

(Received in final form 24 October 2000)

\begin{abstract}
Markov chain models have been used to evaluate probabilities of getting a sequence of wet and dry weeks during South-West monsoon period over the districts Purulia in West Bengal and Giridih in Bihar state and dry farming tract in the state of Maharashtra of India. An index based on the parameters of this model has been suggested to indicate the extend of drought-proneness of a region. This study will be useful to agricultural planners and irrigation engineers to identifying the areas where agricultural development should be focused as a long term drought mitigation strategy. Also this study will contribute toward a better understanding of the climatology of drought in a major drought-prone region of the world.
\end{abstract}

Keywords: Markov chain models; Asymptotic normality; Stationary distribution; Drought

\section{INTRODUCTION}

The word "drought" has been drawn world-wide attention in recent years because of its widespread effect in the USA in 1987-88 (Ahmed, 1991) and its devastating effect in the Somalia in 1991-93, and similar effect in Ethiopia few years ago and in the Sahel region of Africa in the late 1980's. In the rain dependent agricultural regions of the world availability of rainwater is one of the most important considerations of agricultural planning. Rainfall varies from year to year and from place to place, sometimes leading to the occurrence of drought. It is obvious, when drought occurs during climate season, it effects both crop seasons-Hereby increasing the food shortage and misery of the people (Ahmed, 1995). Inference problems, such as estimation and hypothesis testing involving Markov chains have been considered by several authors, Bartlett (1955); Whittle (1955); Anderson and Gordman (1957); Billingsley (1961); Lee et al. (1970) not only because of their theoretical interest but also for their applications in diverse areas. Drought occurs when various

* Corresponding author.

†e-mail: rajucc@citechco.net

ISSN: 1026-0226 (C) 2002 Taylor \& Francis Ltd 
combinations of the physical factors of the environment produce an internal water stress in crop plants sufficient to reduce their productivity. In the low rainfall areas especially in tropics, the importance of rainfall overrides that of all other climatic factors, which determine yield. So, agricultural drought is mainly concerned with inadequacy of rainfall. In Purulia (West Bengal) and Giridih (Bihar) districts and dryland areas of the state of Maharashtra, the rainy season is mainly due to South West monsoon and it ranges from June to September. Hence the crop yield in the area will depend on variation of rainfall in this season.

Drought is temporary but complex feature of the climatic system of a given region with widespread significance (Olapido, 1985), which is usually caused by precipitation deficit (Gregory, 1986). Such natural disasters leave a long lasting effect on a social and economic fabric of a region where it strikes, sometimes requiring relief efforts on a global scale (Ahmed, 1995). Although we can recognize a drought when it hits a given region, there is no universal definition of this term. Various characteristics of droughts, including definitions and their meteorological, hydrological and economic aspects were discussed by Doornkamp et al. (1980); Giambelluca et al. (1988); Landsberg (1982); Dennet et al. (1985); Olapido (1985); Ahmed (1991) and reviewed extensively by Gregory (1986) and Nieuwolt (1986).

Different units of time period are used for rainfall analysis. For agriculture, week may be nearer to the optimum length of time. The week with rainfall greater than the threshold value (a minimum amount, say $2.5 \mathrm{~mm}$ ) is considered to be a wet week. The expected number of wet weeks in a given period of time can decide the crop production of an area. The probability of sequences of wet weeks can indicate the adequacy of water and that of dry weeks indicate the reverse and recurrence of the risk of crop failure. Wet and dry sequences of week can be well represented by the Markov chain model.

\section{DATA AND SAMPLE AREA}

The weekly rainfall data of five stations each for Purulia and Giridih districts were available for 18 to 27 years. The secondary data (Khambete and Biswas, 1984) has been used for the rest 30 stations situated in the dry farming Tract of Maharashtra. As the rainfall season mainly ranges from June to September in the areas under consideration, 22nd to 42 nd standard weeks have been used this study.

\section{Method-1}

Several authors have found that a simple Markov chain model can describe sequences in daily rainfall occurrences. The first successful application of such a model seems to have been made by Gabriel and Neumann (1962) for Tel-Aviv. Additional evidence to indicate the feasibility of using a Markov chain model has been presented by Caskey (1963); Weiss (1964); Hopkins and Robillard (1964); Katz (1974); Todorovic and Woolhiser (1975) and Rahman (1999a, b).

Let $\mathrm{X}_{0}, \mathrm{X}_{1}, \mathrm{X}_{2}, \ldots, \mathrm{X}_{\mathrm{n}}$, be random variables distributed identically and taking only two values, namely 0 and 1 , with probability one, i.e.,

$$
X_{n}= \begin{cases}0 & \text { if the } n \text {th week is dry } \\ 1 & \text { if the } n \text {th week is wet }\end{cases}
$$

Firstly we assume that, $\mathrm{P}\left(\mathrm{X}_{\mathrm{n}+1}=x_{\mathrm{n}+1} \mid \mathrm{X}_{\mathrm{n}}=x_{\mathrm{n}}\right.$. $\left.\mathrm{X}_{\mathrm{n}-1}=x_{\mathrm{n}-1}, \ldots, \mathrm{X}_{0}=x_{0}\right)=\mathrm{P}\left(\mathrm{X}_{\mathrm{n}+1}=x_{\mathrm{n}+1} \mid\right.$ $\left.\mathrm{X}_{\mathrm{n}}=x_{\mathrm{n}}\right)$.

Where $x_{0}, x_{1}, \ldots, x_{\mathrm{n}+1} \in\{0,1\}$. In other words, it is assumed that probability of wetness of any week depends only on whether the previous week was wet or dry. Given the event on previous week, the probability of wetness is assumed independent of further preceding weeks. So the stochastic process $\left\{X_{n}, n=0,1,2, \ldots\right\}$ is a Markov chain (Medhi, 1981; Cox and Miller, 1965). Consider the transition matrix

$$
\left(\begin{array}{ll}
P_{00} & P_{01} \\
P_{10} & P_{11}
\end{array}\right)
$$


where $\mathrm{P}_{i j}=\mathrm{P}\left(\mathrm{X}_{1}=j \mid \mathrm{X}_{0}=i\right) i, j=0,1$. Note $\mathrm{P}_{00}+$ $\mathrm{P}_{01}=1$ and $\mathrm{P}_{10}+\mathrm{P}_{11}=1$.

Let $p=\mathrm{P}\left(\mathrm{X}_{0}=1\right)$. Here $p$ is the absolute probability of a week being wet during the monsoon period. Clearly, $\mathrm{P}\left(\mathrm{X}_{0}=0\right)=1-p$.

For a stationary distribution

$$
\left[\begin{array}{lll}
1 & -p & p
\end{array}\right]\left[\begin{array}{ll}
P_{00} & P_{01} \\
P_{10} & P_{11}
\end{array}\right]=\left[\begin{array}{lll}
1 & -p & p
\end{array}\right]
$$

which gives

$$
p=\frac{P_{01}}{1-\left(P_{11}-P_{01}\right)} .
$$

It is further assumed that $\mathbf{P}_{i j}$ 's remaining constant over the years. The maximum likelihood estimate of $P_{01}$ and $P_{11}$ are appropriate relative functions (Woolhiser and pegram, 1979).

A wet spell of length $k$ is defined as sequences of $k$ wet weeks preceded and followed by weeks. Dry spells are defined correspondingly. By "probability of wet spell of length $k$ " we mean the probability of a wet spell of length $k$ given that this week is wet, i.e.,

$$
P(W=k)=\left(1-P_{11}\right) P_{11}^{k-1}
$$

and probability of wet sequences with length greater than $k$ is:

$$
P(W>k)=\sum_{t=k+1}^{\infty} P(W=t)=P_{11}^{k} .
$$

Similarly, probability of a dry spell of length $\mathrm{m}$ is:

$$
P(D=m)=\left(1-P_{01}\right) P_{01}^{m-1} .
$$

and probability of dry sequences with length greater than $m$ is:

$$
P(D>m)=\left(1-P_{01}\right)^{m} .
$$

Let $\mathrm{Y}$ be the random variable such that $\mathrm{Y}=$ number of wet weeks among a $n$-week period i.e., $\mathrm{Y}=\mathrm{X}_{0}+\mathrm{X}_{1}+\cdots+\mathrm{X}_{\mathrm{n}-1}$.
For large $n, \mathrm{Y}$ follows normal distribution with

$$
\text { Mean }=n \times p
$$

$$
\text { Variance }=n \times p \times(1-p) \times \frac{1+P_{11}-P_{01}}{1-P_{11}+P_{01}}
$$

Where $p$ is the stationary probability of a week being wet.

This is an asymptotic result which indicates neither the exact distribution for small $\mathrm{n}$ nor the rapidly of approach to normality (Feller, 1957).

\section{INDEX OF DROUGHT-PRONENESS}

$\mathrm{P}_{11}$ gives the probability of a week to be wet given that previous week was wet also. When $P_{11}$ is large, the chance of wet weeks is also large. But only a small of $P_{11}$ may not indicate high droughtproneness. In this case, large value of $\mathrm{P}_{01}$ implies a large number of short wet spells which can prevent occurrence of drought. Hence an index of droughtproneness may be defined as:

$$
\mathrm{D} I=\mathrm{P}_{11} \times \mathrm{P}_{01}
$$

Zero and one bound this index of droughts. Higher the value of DI, lower will be the degree of drought-proneness. The extent of droughtproneness is given below:

\section{Method 2}

Under the same set up, now assume

$$
\begin{aligned}
& \mathrm{P}\left(\mathrm{X}_{\mathrm{n}+1}=x_{\mathrm{n}+1} \mid \mathrm{X}_{\mathrm{n}}=x_{\mathrm{n}}, \ldots, \mathrm{X}_{0}=x_{0}\right) \\
& \quad=\mathrm{P}\left(\mathrm{X}_{\mathrm{n}+1}=x_{\mathrm{n}+1} \mid \mathrm{X}_{\mathrm{n}}=x_{\mathrm{n}}, \mathrm{X}_{\mathrm{n}-1}=x_{\mathrm{n}-1}\right)
\end{aligned}
$$

TABLE I Index of drought-proneness

\begin{tabular}{lc}
\hline Criteria & Degree of drought-proneness \\
\hline $0.000 \leq \mathrm{DI} \leq 0.125$ & Chronic \\
$0.125<\mathrm{DI}<0.180$ & Severe \\
$0.180<\mathrm{DI} \leq 0.235$ & Moderate \\
$0.235<\mathrm{DI} \leq 0.310$ & Mild \\
$0.310<\mathrm{DI} \leq 1.000$ & Occasional \\
\hline
\end{tabular}


where $x_{0}, x_{1}, \ldots, x_{\mathrm{n}+1} \in\{0,1\}$. In other words, it is assumed that probability of wetness of any week depends only on whether the two preceding weeks were wet or dry. Given the event on previous two weeks, the probability of wetness is independent of further preceding weeks.

Now define

$$
\begin{aligned}
Y_{0}= & \left(X_{0}, X_{1}\right), Y_{1}=\left(X_{2}, X_{3}\right) \\
& Y_{2}\left(X_{4}, X_{5}\right), \ldots, Y_{n}\left(X_{2 n}, X_{2 n+1}\right)
\end{aligned}
$$

Now,

$$
\begin{aligned}
\mathrm{P}\left(\mathrm{Y}_{\mathrm{n}+1}\right. & \left.=\mathrm{y}_{\mathrm{n}+1}\left|\mathrm{Y}_{\mathrm{n}}=\mathrm{y}_{\mathrm{n}}, \mathrm{Y}_{\mathrm{n}-1}\right| \mathrm{y}_{\mathrm{n}-1}, \ldots, \mathrm{Y}_{0}=\mathrm{y}_{0}\right) \\
& =\mathrm{P}\left(\mathrm{Y}_{\mathrm{n}+1}=\mathrm{y}_{\mathrm{n}+1} \mid \mathrm{Y}_{\mathrm{n}}=\mathrm{y}_{\mathrm{n}}\right)
\end{aligned}
$$

where

$\mathrm{y}_{0}, \mathrm{y}_{1}, \ldots, \mathrm{y}_{\mathrm{n}+1} \in\{(0,0),(0,1),(1,0),(1,1)\}$. Now the stochastic process $\left\{Y_{n}, n=0,1,2, \ldots\right\}$ is a Markov chain (Bhat, 1972; Ochi, 1990 and Chung, 1974).

Consider the transition matrix

$$
\left[\begin{array}{llll}
a_{00} & a_{01} & a_{02} & a_{03} \\
a_{10} & a_{11} & a_{12} & a_{13} \\
a_{20} & a_{21} & a_{22} & a_{23} \\
a_{30} & a_{31} & a_{32} & a_{33}
\end{array}\right]
$$

where $a_{i j}=P\left(Y_{1}=j \mid Y_{0}=i\right)$

$$
i \text { or } j= \begin{cases}0 & \text { stands for the state }(0,0) \\ 1 & \text { stands for the state }(0,1) \\ 2 & \text { stands for the state }(1,0) \\ 3 & \text { stands for the state }(1,1)\end{cases}
$$

Let $\mathbf{P}_{(0,0)}-\mathbf{P}_{1}, \mathbf{P}_{(0,1)}-\mathbf{P}_{2}, \mathbf{P}_{(1,0)}-\mathbf{P}_{3}, \mathbf{P}_{(1,1)}-\mathbf{P}_{4}$. Note that $\Sigma_{\mathrm{i}=1}^{4} \mathbf{P}_{\mathrm{i}}=1 ; \Sigma_{\mathrm{j}=0}^{3} \mathbf{a}_{\mathrm{ij}}=1, \mathrm{i}=0,1,2,3$.

For a stationary distribution,

$$
\begin{aligned}
& {\left[\begin{array}{llll}
\mathbf{P}_{1} & \mathbf{P}_{2} & \mathbf{P}_{3} & \mathbf{P}_{4}
\end{array}\right]\left[\begin{array}{llll}
a_{00} & a_{01} & a_{02} & a_{03} \\
a_{10} & a_{11} & a_{12} & a_{13} \\
a_{20} & a_{21} & a_{22} & a_{23} \\
a_{30} & a_{31} & a_{32} & a_{33}
\end{array}\right]} \\
& =\left[\begin{array}{llll}
\mathbf{P}_{1} & \mathbf{P}_{2} & \mathbf{P}_{3} & \mathbf{P}_{4}
\end{array}\right]
\end{aligned}
$$

Here, when we find the probability of a wet spell of length $k$, we actually mean it is the probability of a wet spell of length $k$ given that this week is wet and the previous week was a dry one. Similarly we account for dry spells also.

$\mathrm{P}(\mathrm{W}=k)=\mathrm{P}($ Wet spell of length $k \mid$ this week is wet and previous week was dry)

$$
\begin{gathered}
\begin{aligned}
\mathrm{P}(\mathrm{W}=k) \quad & k \text { odd }, \quad k \geq 3 \\
= & \mathrm{P}(\mathrm{W}=2 m-1) \quad m \geq 2 \\
= & a_{13} a_{33}^{m-2}\left(a_{30}+a_{31}\right)
\end{aligned} \\
\mathrm{P}(\mathrm{W}=k) \quad \begin{array}{c}
k \text { even, } \quad k \geq 4 \\
=
\end{array} \\
=a_{13} a_{33}^{n-2} a_{32} \\
\mathrm{P}(\mathrm{W}=2)=\mathrm{P}((1,0) \mid(0,1))=a_{12} \\
\mathrm{P}(\mathrm{W} \geq 2 t)=\sum_{k=2 t}^{\infty} P(W=k), \quad t \geq 2 \\
=\left(a_{32}+a_{33}\left(a_{30}+a_{31}\right)\right) \frac{a_{13} a_{33}^{t-2}}{1-a_{33}} \\
\mathrm{P}(\mathrm{W} \geq 2 t-1)=\mathrm{P}(\mathrm{W} \geq 2 t) \\
+\mathrm{P}(\mathrm{W}=2 t-1), \quad t \geq 2 \\
=a_{13} a_{33}^{t-2} .
\end{gathered}
$$

Similarly, $\mathrm{P}(\mathrm{D}=k)=($ Dry spell of length $k \mid$ this week is dry and the previous week was wet)

$$
\begin{array}{cc}
\mathrm{P}(\mathrm{D}=k) \quad k \text { odd }, \quad k \geq 3 \\
= & \mathrm{P}(\mathrm{D}=2 m-1) \quad m \geq 2 \\
= & a_{20} a_{00}^{m-2}\left(a_{02}+a_{03}\right) . \\
\mathrm{P}(\mathrm{D}=k) \quad & k \text { even, } \quad k \geq 4 \\
= & \mathrm{P}(\mathrm{D}=2 n) \quad n \geq 2 \\
= & a_{20} a_{00}^{n-2} a_{01} .
\end{array}
$$

Also,

$$
\mathrm{P}(\mathrm{D} \geq 2 t)=\left(a_{01}+a_{00}\left(a_{02}+a_{03}\right)\right) \frac{a_{02} a_{00}^{t-2}}{1-a_{00}}, \quad t \geq 2
$$

$$
\begin{aligned}
\mathrm{P}(\mathrm{D} \geq 2 t-1) & =\mathrm{P}(\mathrm{D} \geq 2 t)+\mathrm{P}(\mathrm{D}=2 t-1) \\
& =a_{20} a_{00}^{t-2}, \quad t \geq 2
\end{aligned}
$$


Let $\mathrm{U}$ be the random variable such that $\mathrm{U}=$ number of wet weeks among $2 n$-week period. Therefore, $\mathrm{U}=f\left(\mathrm{Y}_{0}\right)+f\left(\mathrm{Y}_{1}\right)+\cdots+f\left(\mathrm{Y}_{\mathrm{n}-1}\right)$ where

$$
\begin{aligned}
& f(0,0)=0 \\
& f(0,1)=1 \\
& f(1,0)=1 \\
& f(1,1)=2
\end{aligned}
$$

For large $n, \mathrm{U} \sim \mathrm{N}\left(n \mu, n \sigma^{2}\right)$ [for large $n, 2 n \approx$ 2n-1] (Feller, 1957; Medhi, 1981)

Where

$$
\begin{aligned}
& \mu=f(0,0) \times \mathrm{P}_{1}+f(0,1) \times \mathrm{P}_{2}+f(1,0) \\
& \times \mathrm{P}_{3}+f(1,1) \times \mathrm{P}_{4} \\
& \sigma^{2}=F^{\prime} C F \\
& \mathrm{~F}-\left(\begin{array}{c}
f(0,0) \\
f(0,1) \\
f(1,0) \\
f(1,1)
\end{array}\right)
\end{aligned}
$$

and $\mathrm{C}=\left(\mathrm{c}_{i j}\right)$ where $\mathrm{c}_{i j}=\mathrm{P}_{i} z_{i j}+\mathrm{P}_{j} z_{j i}-\mathrm{P}_{i} \delta_{i j}-\mathbf{P}_{i} \mathbf{P}_{j}$

$$
\text { where } \quad \delta_{i j}= \begin{cases}1 & \text { if } i=j \\ 0 & \text { otherwise }\end{cases}
$$

$$
\begin{aligned}
\mathrm{Z} & =\left(\left(z_{i j}\right)\right) \\
& =\left(\begin{array}{cccc}
1+P_{1}-a_{00} & P_{2}-a_{01} & P_{3}-a_{02} & P_{4}-a_{03} \\
P_{1}-a_{10} & 1+P_{2}-a_{11} & P_{3}-a_{12} & P_{4}-a_{13} \\
P_{1}-a_{20} & P_{2}-a_{21} & 1+P_{3}-a_{22} & P_{4}-a_{23} \\
P_{1}-a_{30} & P_{2}-a_{31} & P_{3}-a_{32} & 1+P_{4}-a_{33}
\end{array}\right)^{-1}
\end{aligned}
$$

\section{RESULTS AND DISCUSSIONS}

Drought causes abnormal loss of water from water bodies, lowering of the water table and dehydration of the root zone of the soil, thus upsetting water supply to the plants. For the purpose of the analysing agricultural drought, the loss of moisture from the soil reservoir should be given much attention. Scientists use precipitation, evapotranspiration and available soil moisture in the root zone as inputs of quantify droughts in various parts of the world. Among these factors, precipitation (which is only rainfall in case of Purulia and Giridih districts and dry farming tracts of Maharashtra) plays the pivotal rule in determining drought-proneness.

The choice of threshold value for Markov Chain model is very important, especially when it is used for agricultural purpose. A small amount of water in dry regions may be very much useful whereas the same amount may be insignificant in humid regions.

Tables II and III give the values of $\mathrm{p}, \mathrm{P}_{11}$ and $P_{01}$ discussed in Method 1. In Table III values of $P_{01}$ and $P_{11}$ are taken as secondary data (Khambete and Biswas, 1984). $P_{11}$ is always greater than p. i.e., conditional probability is always greater than stationary probability which suggests that the effect of persistence is significant (Rahman, 1999b). In Tables II and III expected number of wet weeks are computed from Eqs. (4) and (5) and assuming distribution of wet weeks to be normal, the probabilities of getting more than $8,10,12$ wet weeks are computed. Experience shows that generally to harvest a good crop 10 to 12 wet weeks are necessary. When there is a continuous span of at least three dry weeks between the wet weeks the crop can not be sustained. Hence the probability of sequences of more than three dry weeks are computed from Eq. (3).

Table IV gives the values of $\mathrm{P}_{1}, \mathrm{P}_{2}, \mathrm{P}_{3}$ and $\mathrm{P}_{4}$ discussed in Method 2 for the stations of Purulia and Giridih districts. Here the probabilities of getting at least 8,10 , and 12 wet weeks are computed under assumption of normality using Eqs. (8) and (9). But the corresponding probabilities given in Table II are more reliable because of the conditions for assumption of normality are more favourable for Method 1 (Rahman, 1999a). On the otherhand, probability of a dry spell of length at least 3 weeks given in Table III, calculated using Eq. (7) is more satisfactory compared to the given in Table II because, in this case, exact probabilities are calculated without any asymptotic assumption (Medhi, 1981). 
TABLE II Probability of wet and dry weeks and index of drought-proneness in various stations of Purulia and Giridih (Method 1)

\begin{tabular}{|c|c|c|c|c|c|c|c|c|c|}
\hline \multirow[b]{2}{*}{ Station } & \multirow[b]{2}{*}{$p$} & \multirow[b]{2}{*}{$P_{11}$} & \multirow[b]{2}{*}{$P_{01}$} & \multirow[b]{2}{*}{$E(Y)$} & \multicolumn{3}{|c|}{ Probability of getting wet weeks at least } & \multirow[b]{2}{*}{$P(D>3)$} & \multirow[b]{2}{*}{ DI } \\
\hline & & & & & 8 & 10 & 12 & & \\
\hline Baghmundi & 0.53 & 0.74 & 0.29 & 11.07 & 0.79 & 0.61 & 0.40 & 0.36 & 0.21 \\
\hline Barabazar & 0.52 & 0.73 & 0.29 & 11.01 & 0.79 & 0.61 & 0.32 & 0.35 & 0.21 \\
\hline Jhalda & 0.52 & 0.73 & 0.29 & 10.96 & 0.79 & 0.60 & 0.39 & 0.35 & 0.21 \\
\hline Kashipur & 0.53 & 0.75 & 0.28 & 11.22 & 0.80 & 0.62 & 0.42 & 0.37 & 0.21 \\
\hline Para & 0.52 & 0.74 & 0.28 & 10.95 & 0.79 & 0.60 & 0.39 & 0.37 & 0.21 \\
\hline Bengabad & 0.49 & 0.71 & 0.27 & 10.21 & 0.72 & 0.52 & 0.31 & 0.39 & 0.19 \\
\hline Gandey & 0.49 & 0.76 & 0.23 & 10.25 & 0.71 & 0.52 & 0.33 & 0.45 & 0.18 \\
\hline Giridih & 0.47 & 0.76 & 0.22 & 9.84 & 0.67 & 0.48 & 0.30 & 0.48 & 0.16 \\
\hline Jamua & 0.38 & 0.76 & 0.15 & 8.01 & 0.50 & 0.33 & 0.19 & 0.62 & 0.11 \\
\hline Palganj & 0.50 & 0.78 & 0.22 & 10.55 & 0.72 & 0.55 & 0.37 & 0.47 & 0.17 \\
\hline
\end{tabular}

TABLE III Probability of wet and dry weeks and index of drought-proneness in various stations of dry farming tract of Maharashtra (Method 1)

\begin{tabular}{|c|c|c|c|c|c|c|c|c|c|}
\hline \multirow[b]{2}{*}{ Station } & \multirow[b]{2}{*}{$p$} & \multirow[b]{2}{*}{$P_{11}$} & \multirow[b]{2}{*}{$P_{01}$} & \multirow[b]{2}{*}{$E(Y)$} & \multicolumn{3}{|c|}{ Probability of getting wet weeks at least } & \multirow[b]{2}{*}{$P(D>3)$} & \multirow[b]{2}{*}{ DI } \\
\hline & & & & & 8 & 10 & 12 & & \\
\hline Sangli & 0.38 & 0.48 & 0.32 & 8.01 & 0.50 & 0.24 & 0.08 & 0.46 & 0.15 \\
\hline Jath & 0.33 & 0.44 & 0.28 & 6.98 & 0.35 & 0.13 & 0.03 & 0.52 & 0.12 \\
\hline Vita & 0.37 & 0.48 & 0.33 & 7.86 & 0.48 & 0.21 & 0.06 & 0.44 & 0.15 \\
\hline Satara & 0.57 & 0.66 & 0.46 & 12.00 & 0.91 & 0.75 & 0.50 & 0.39 & 0.30 \\
\hline Pusesawli & 0.38 & 0.48 & 0.31 & 7.89 & 0.48 & 0.23 & 0.07 & 0.47 & 0.15 \\
\hline Mhaswad & 0.28 & 0.37 & 0.21 & 5.81 & 0.19 & 0.05 & 0.01 & 0.58 & 0.09 \\
\hline Dahiwadi & 0.29 & 0.40 & 0.25 & 6.19 & 0.24 & 0.07 & 0.01 & 0.56 & 0.10 \\
\hline Pune & 0.46 & 0.55 & 0.39 & 9.73 & 0.73 & 0.46 & 0.21 & 0.37 & 0.21 \\
\hline Baramati & 0.29 & 0.38 & 0.26 & 6.18 & 0.24 & 0.07 & 0.01 & 0.55 & 0.10 \\
\hline Indapur & 0.33 & 0.43 & 0.28 & 6.83 & 0.33 & 0.12 & 0.03 & 0.52 & 0.12 \\
\hline Dhond & 0.32 & 0.42 & 0.28 & 6.74 & 0.32 & 0.11 & 0.02 & 0.52 & 0.11 \\
\hline Nasik & 0.47 & 0.55 & 0.39 & 6.81 & 0.74 & 0.47 & 0.22 & 0.37 & 0.22 \\
\hline Sinnei & 0.42 & 0.49 & 0.37 & 8.87 & 0.62 & 0.34 & 0.13 & 0.40 & 0.18 \\
\hline Malegaon & 0.38 & 0.44 & 0.34 & 7.98 & 0.50 & 0.22 & 0.06 & 0.43 & 0.15 \\
\hline Dhule & 0.46 & 0.52 & 0.40 & 9.59 & 0.72 & 0.44 & 0.09 & 0.36 & 0.21 \\
\hline Sakri & 0.37 & 0.47 & 0.32 & 7.85 & 0.48 & 0.22 & 0.07 & 0.47 & 0.15 \\
\hline Sholapur & 0.45 & 0.51 & 0.41 & 9.54 & 0.72 & 0.43 & 0.18 & 0.35 & 0.21 \\
\hline Sangola & 0.33 & 0.50 & 0.30 & 7.03 & 0.35 & 0.12 & 0.03 & 0.49 & 0.12 \\
\hline Madha & 0.40 & 0.45 & 0.37 & 8.36 & 0.55 & 0.26 & 0.08 & 0.40 & 0.16 \\
\hline Ahmednagar & 0.39 & 0.47 & 0.34 & 8.19 & 0.53 & 0.25 & 0.08 & 0.44 & 0.16 \\
\hline Mirajgaon & 0.37 & 0.44 & 0.34 & 7.82 & 0.47 & 0.20 & 0.06 & 0.44 & 0.15 \\
\hline Jagaon & 0.53 & 0.65 & 0.40 & 11.12 & 0.84 & 0.64 & 0.39 & 0.36 & 0.26 \\
\hline Buldhana & 0.57 & 0.64 & 0.48 & 11.99 & 0.92 & 0.76 & 0.50 & 0.27 & 0.31 \\
\hline Akola & 0.53 & 0.61 & 0.43 & 11.03 & 0.85 & 0.64 & 0.37 & 0.32 & 0.26 \\
\hline Amravati & 0.58 & 0.66 & 0.47 & 12.18 & 0.92 & 0.77 & 0.52 & 0.28 & 0.31 \\
\hline Osmanabad & 0.55 & 0.61 & 0.47 & 11.53 & 0.89 & 0.71 & 0.43 & 0.28 & 0.29 \\
\hline Bhir & 0.45 & 0.53 & 0.39 & 9.53 & 0.71 & 0.43 & 0.19 & 0.37 & 0.21 \\
\hline Aurangabad & 0.53 & 0.61 & 0.43 & 11.07 & 0.85 & 0.64 & 0.37 & 0.32 & 0.26 \\
\hline Parbhani & 0.55 & 0.61 & 0.47 & 11.49 & 0.89 & 0.70 & 0.43 & 0.28 & 0.29 \\
\hline Nanded & 0.61 & 0.69 & 0.43 & 12.73 & 0.94 & 0.82 & 0.60 & 0.28 & 0.33 \\
\hline
\end{tabular}

\section{CHRONIC DROUGHT-PRONE AREA}

Drought index of the area is less than 0.125 (Tab. I).

Once in three years more than three cosecutive dry weeks are expected in this area, hence it is defined as a chronic drought-prone area. Expected number of wet weeks is $6-7$. Early withdrawal of monsoon would affect the crop severely. More than 10 wet 
TABLE IV Probability of wet and dry weeks in various stations of Purulia and Giridih districts (Method 2)

\begin{tabular}{|c|c|c|c|c|c|c|c|c|c|}
\hline \multirow[b]{2}{*}{ Station } & \multirow[b]{2}{*}{$P_{1}$} & \multirow[b]{2}{*}{$P_{2}$} & \multirow[b]{2}{*}{$P_{3}$} & \multirow[b]{2}{*}{$P_{4}$} & \multirow[b]{2}{*}{$E(U)$} & \multicolumn{3}{|c|}{ Probability of getting wet weeks at least } & \multirow[b]{2}{*}{$P(D>3)$} \\
\hline & & & & & & 8 & 10 & 12 & \\
\hline Baghmundi & 0.32 & 0.13 & 0.13 & 0.41 & 10.90 & 0.72 & 0.57 & 0.41 & 0.31 \\
\hline Barabazar & 0.33 & 0.13 & 0.13 & 0.40 & 10.77 & 0.71 & 0.56 & 0.40 & 0.31 \\
\hline Jhalda & 0.38 & 0.12 & 0.13 & 0.37 & 9.97 & 0.64 & 0.50 & 0.35 & 0.35 \\
\hline Kashipur & 0.37 & 0.12 & 0.13 & 0.38 & 10.06 & 0.65 & 0.50 & 0.36 & 0.35 \\
\hline Para & 0.37 & 0.12 & 0.13 & 0.38 & 10.95 & 0.66 & 0.51 & 0.37 & 0.34 \\
\hline Bengabad & 0.31 & 0.13 & 0.14 & 0.39 & 10.50 & 0.69 & 0.51 & 0.38 & 0.32 \\
\hline Gandey & 0.35 & 0.13 & 0.13 & 0.39 & 10.40 & 0.68 & 0.53 & 0.38 & 0.33 \\
\hline Giridih & 0.36 & 0.13 & 0.13 & 0.38 & 10.19 & 0.66 & 0.51 & 0.37 & 0.35 \\
\hline Jamua & 0.38 & 0.12 & 0.12 & 0.37 & 9.86 & 0.63 & 0.49 & 0.35 & 0.36 \\
\hline Palganj & 0.37 & 0.12 & 0.12 & 0.38 & 10.10 & 0.66 & 0.51 & 0.37 & 0.35 \\
\hline
\end{tabular}

weeks are expected once only in 5 or 6 years. Crop prospects are high only in these years. Only Jamua $(\mathrm{DI}=.11)$ station is chronic drought-prone area (Tab. II) and Table III suggest that Jath (DI $=.12)$, Mhaswad $\quad(\mathrm{DI}=.09)$, Dahiwadi $\quad(\mathrm{DI}=.10)$, Baramati $(\mathrm{DI}=.10)$, Indapur $(\mathrm{DI}=.12)$, Dhond $(\mathrm{DI}=0.11)$, Malegaon $(\mathrm{DI}=.15)$ and Sangola $(\mathrm{DI}=.12)$ stations are chronic drought-prone area.

\section{SEVERELY DROUGHT-PRONE AREA}

Drought index of the area lies between 0.125 and 0.180 (Tab. I). The expected number of wet weeks is $8-9$. As it is expected to get more than 10 weeks once in 4 or 5 years, some potential of ground water recharge is there. The probability of getting of dry spell of length more than 3 weeks is greater than 0.3 . So this area may be defined as severely drought prone area. Severely drought prone areas are found in the following three stations (Tab. II) which are Giridih (DI =.16), Palganj (DI =.17), and Gandey $(\mathrm{DI}=.18)$ and also eight stations (Tab. III) are severely drought-prone namely, Sangli $(\mathrm{DI}=.15)$, Vita $(\mathrm{DI}=.15), \quad$ Pusesawli $\quad(\mathrm{DI}=.15), \quad$ Sinnei $(\mathrm{DI}=.18)$, Sakri $(\mathrm{DI}=.15)$, Madha $(\mathrm{DI}=.16)$, Ahmednagar (DI =.16) and Mirajgaon $(\mathrm{DI}=.15)$ of dry farming Tract of Maharashtra.

\section{MODERATELY DROUGHT-PRONE AREA}

Drought index of the area lies between 0.180 and 0.235 (Tab. I). The expected number of wet weeks is 10 . The probability of getting more than 3 consecutive dry weeks is less than 0.2. Here more than 10 wet weeks are expected thrice in five years. A good crop may be expected during this period. Among three districts, six stations (Tab. II) found moderately drought prone area (Baghmundi $(\mathrm{DI}=.21)$, Barabazar $(\mathrm{DI}=.21)$, Jhalda $(\mathrm{DI}=.21)$, Kashipur $(\mathrm{DI}=.21)$, Para $(\mathrm{DI}=.21)$, and Bengabad $(\mathrm{DI}=.19))$ and only four stations (Tab. III) Pune $(\mathrm{Di}=.21)$, Nasik $(\mathrm{DI}=.22)$, Dhule $(\mathrm{DI}=.21)$, Sholapur $(\mathrm{DI}=.21)$ and Bhir $(\mathrm{DI}=.21)$ are also moderately droughtprone area.

\section{MILD DROUGHT-PRONE AREA}

Drought index of the area lies between 0.235 and 0.310 (Tab. I). The expected number of wet weeks is 11-12. 4 times in 5 years more than 10 wet weeks are expected. A good crop may be expected in this region. Eight stations of Dry farming Tract of Maharashtra are mild- drought prone area (Tab. III) i.e., Satara $(\mathrm{DI}=.30)$, Jagaon $(\mathrm{DI}=.26)$, Buldhana $(\mathrm{DI}=.31)$, Akola $(\mathrm{DI}=.26), \quad$ Amravati $\quad(\mathrm{DI}=.30), \quad$ Osmanabad $(\mathrm{DI}=.29)$, Aurangabad $(\mathrm{DI}=.26)$ and Parbhani $(\mathrm{DI}=.29)$.

\section{OCCASIONAL DROUGHT-PRONE AREA}

Drought index of the area is more than 0.310 (Tab. I). Once in 10 years these areas may get less 
than 10 wet weeks. Expected number of wet weeks is more than 12. Good potential of ground water recharge is there hence this area is considered as occasionally drought-prone area. Good crop can be harvested more or less regularly. There is not found any occasionally drought prone area in the station of Purulia and Giridih districts. Exceptionally only one station Namded $(\mathrm{DI}=.33$ ) among 30 stations of dry farming Tract of Maharashtra is occasionally drought prone area (Tab. III).

\section{CONCLUSIONS}

Markov Chain model has been fitted to weekly rainfall data to obtain sequences of dry and wet spells during the monsoon season. These sequences of wet and dry spells can be an aid to understand drought-proneness which has been identified with the help of a simple index. In chronic droughtprone areas the crop failure is very frequent. A good crop may be raised in about $35 \%$ of the years in severe drought prone areas. In moderately and mild drought-prone areas a good crop may be harvested in about $40-50 \%$ and $50-55 \%$ of the years respectively and crop prospect is high in occasionally drought-prone areas. Results can be improved by superimposing atmospheric demand and soil characteristics of the region on these results. This study will contribute toward a better understanding of the climatology of drought in major monsoon region of the world. The results of this paper will be useful to agricultural planners and irrigation engineers to identifying the areas where agricultural development should be focused as a long term drought mitigation strategy.

\section{Acknowledgements}

Authors are greatly thankful to Prof. B. V. Rao, Prof. S. C. Bagchi, Prof. D. Sengupta, Prof. D. Bagchi and Prof. T. J. Rao for their valuable comments. Thanks are also to Khambete and Biswas (1984) and Agricultural Science Unit of ISI for collection and compilation of data.

\section{References}

Ahmed, R. (1995) Probabilistic duration of agricultural drought in Bangladesh during the per-monsoon season. Six International Meeting on Statistical Climatology, University College, Galway, Ireland.

Ahmed, R. (1995) An investigation of drought risk in Bangladesh during the pre-monsoon season. Ninth Conference on Applied Climatology, Dallas, Texas, U.S.A. American Meteorological Society, Boston, Massachusetts, U.S.A.

Ahmed, R. (1991) The 1987-88 drought in selected northcentral States of the U.S.A. Geographical Bulletin, 33, 30-36.

Anderson, T. W. and Goodman, L. A. (1957) Statistical inference about Markov Chains. Annals of Mathematics and Statistics, 28, 89-110.

Bartlett, M. S. (1955) Introduction to Stochastic Process, Cambridge University Press, New York.

Billingsley, P. (1961) Statistical methods in Markov Chains. Annals of Math. and Stat., 32, 12-40.

Billingsley, P. (1961) Statistical Inference for Markov Process. University of Chicago-Press, U.S.A.

Bhat, U. N. (1972) Elements of Applied Stochastic Process, Wiley, New York.

Caskey, J. E. (1963) A Markov chain model for probability of precipitation occurrences in intervals of various Length. Monthly Weather Review, 91, 298.

Chung, K. L. (1974) A Course in Probability Theory. Academic Press, New York.

Cox, D. R. and Miller, H. D. (1965) The Theory of Stochastic Process. Wiley, New York.

Dennet, M. D., Elston, J. and Rodgers, J. A. (1985) A reappraisal of rainfall trends in the Sahel. Journal of Climatology, 5, 353-361.

Doorn Kamp, J. C., Gergory, J. K. and Burns, A. S. (Eds.) (1980) Atlas of Drought in Britain 1975-76. Institute of British Geographers, London.

Feller, W. (1957) An Introduction to Probability Theory and Its Application Vol. 1, John Wiley \& Sons, New York.

Gabriel, K. R. and Neumann, J. (1962) On the frequency distribution of dry and wet spells at TelAviv, Quarterly Journal of Royal Meteorological Society, 88, 90 .

Giambelluca, T. W., Nullet, D. and Nullet, M. A. (1988) Agricultural drought of south- central pacific Islands, Professional Geography, 40, 404-415.

Gregory, S. (1986) The Climatology of drought. Geography, 71, $97-104$.

Hopkins, J. and Robillard, P. (1964) Some statistics of daily rainfall occurrence for the Canadian Prairie Providences. Journal of Applied Meteorology, 3, 600.

Kazt, R. W. (1974) Computing probabilistics associated with the Markov chain model for precipitation. Journal of Applied Meteorology, 53, 953.

Landsberg, H. E. (1982) Climatic aspects of drought. Bulletin of American Meteorological Society, 63, 593-596.

Lee, T. C., Judge, G. G. and Zellner, A. (1970) Estimating the parameters of the Markov probability model for aggregate time series data. North Holland, Amsterdam.

Medhi, J. (1981) Stochastic Process, John Wiley \& Sons.

Nieuwolt, S. (1986) Agricultural droughts in the tropic. Theoretical and Applied Climatology, 37, 29-38.

Ochi, M. K. (1990) Applied Probability and Stochastic Process, John Wiley \& Sons. 
Olapido, E. O. (1985) A Comparative performance of three meteorological drought indices. Journal of Climatology, 5, $655-664$

Rahman, M. S. (1999a) A stochastic simulated first-order Markov chain model for daily rainfall at Barind, Bangladesh. Journal of Interdisciplinary Mathematics, 2(1), 7-32.

Rahman, M. S. (1999b) Logistic regression estimation of a simulated Markov chain model for daily rainfall in Bangladesh. Journal of Interdisciplinary Mathematics, 2(1), 33-40.

Todorovic, P. and Woolhiser, D. A. (1975) A Stochastic model of n-day precipitation. Journal of Applied Meteorology, 14, 17.
Weiss, I. I. (1964) Sequences of wet and dry days described by a Markov chain probability model. Monthly Weather Review, 92, 160 .

Whittle, P. (1955) Some distribution and moment formulae for the Markov chains. Journal of Royal Statistical society, B17, 235-242.

Woolhiser, D. A. and Pegram, G. G. S. (1979) Maximum likelihood estimation of Fourier coefficients to describe seasonal variations of parameters in stochastic daily precipitation models. Journal of Applied Meteorology, 14, 17. 


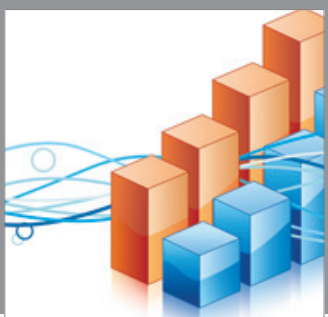

Advances in

Operations Research

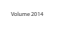

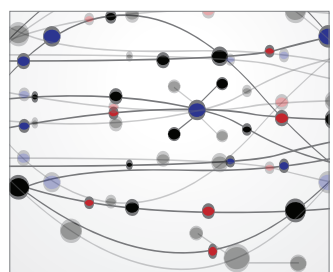

\section{The Scientific} World Journal
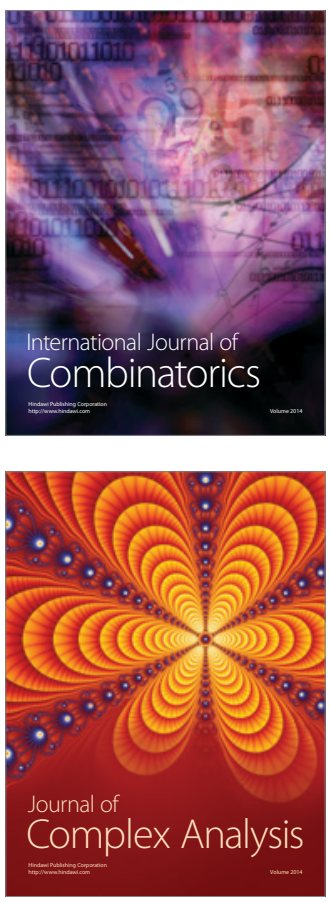

International Journal of

Mathematics and

Mathematical

Sciences
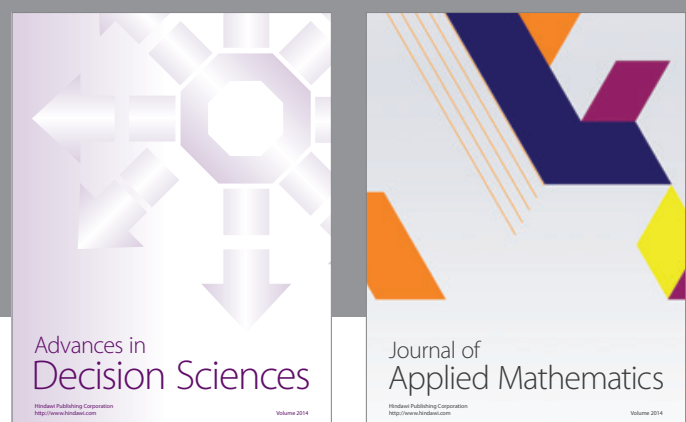

Journal of

Applied Mathematics
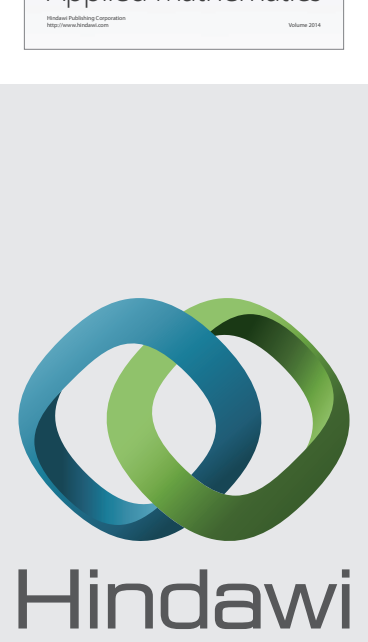

Submit your manuscripts at http://www.hindawi.com
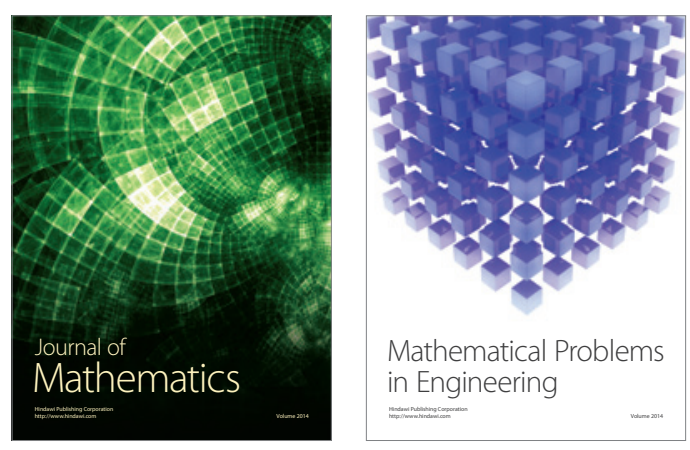

Mathematical Problems in Engineering
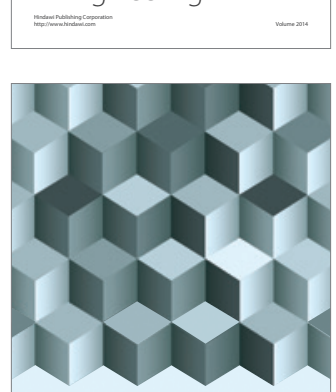

Journal of

Function Spaces
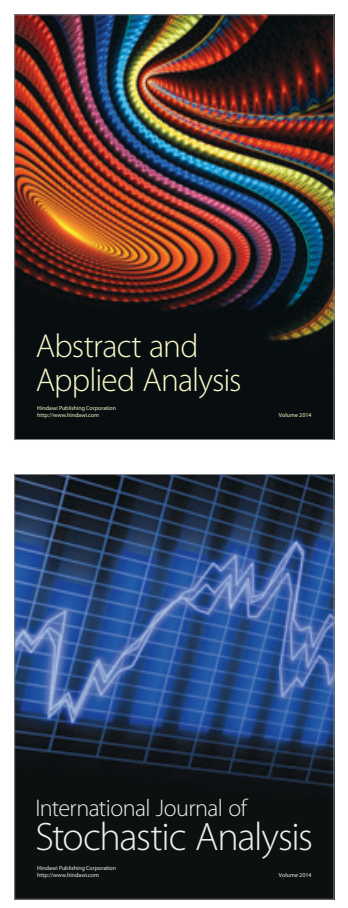

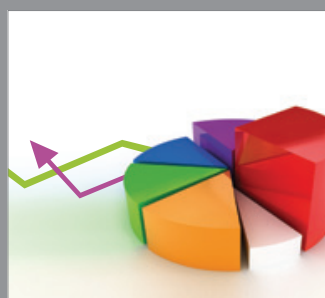

ournal of

Probability and Statistics

Promensencen
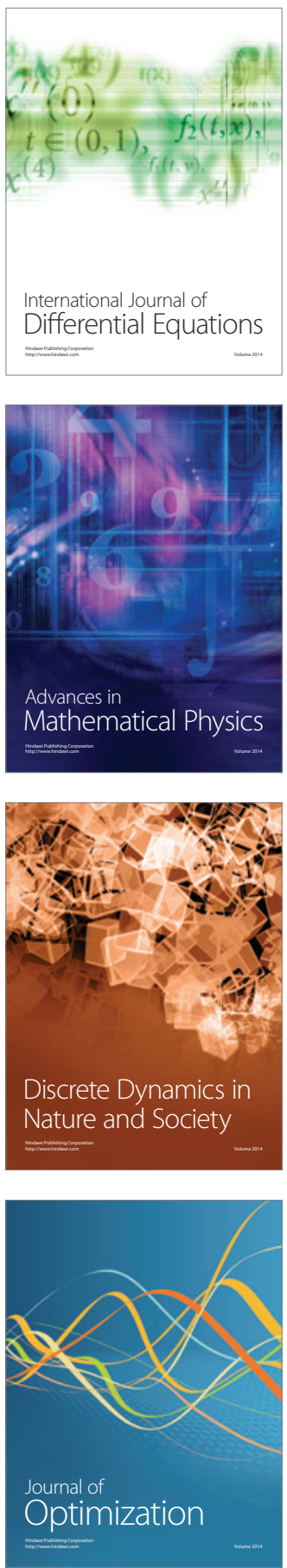